Economics Working Paper Series

2017/007

\title{
The Effect of Far Right Parties on the Location Choice of Immigrants: Evidence from Lega Nord Mayors
}

\author{
Emanuele Bracco, Maria De Paola, Colin Green \\ and Vincenzo Scoppa
}

The Department of Economics

Lancaster University Management School

Lancaster LA1 4YX

UK provided that full acknowledgement is given. 


\title{
The Effect of Far Right Parties on the Location Choice of Immigrants: Evidence from Lega Nord Mayors*
}

\author{
Emanuele Bracco ${ }^{1}$, Maria De Paola ${ }^{2,3}$, Colin Green ${ }^{1}$ and Vincenzo Scoppa ${ }^{2,3}$ \\ ${ }^{1}$ Management School, Lancaster University \\ 2 Department of Economics, Statistics and Finance, University of Calabria \\ ${ }^{3}$ Institute for the Study of Labor (IZA), Bonn, Germany
}

\begin{abstract}
Immigration has increasingly taken centre-stage in the political landscape. Part of this has been rise in far-right, antiimmigration parties in a range of countries. Existing evidence suggests that the presence of immigrants has a substantial effect on the political views of the electorate, generating an advantage to these parties with anti-immigration or nationalist platforms. This paper explores a closely related issue but overlooked issue: how immigrant behavior is influenced by these parties. We focus on immigrant location decisions in Northern Italy which has seen the rise of the anti-immigration party Lega Nord. We construct a dataset of mayoral elections in Italy for the years 2002-2014, and calculate the effect of electing a mayor belonging to, or supported by Lega Nord. To identify this relationship we focus on mayors who have been elected with narrow margins of victory in a Regression Discontinuity framework. The election of Lega Nord mayor discourages immigrants from moving into the municipality.
\end{abstract}

Keywords: Immigration; Geographical Mobility; Voting Behavior; Political economy; Regression Discontinuity Design.

JEL Classification: J15; J61; D72;

\footnotetext{
* The authors would like to thank seminar and conference participants at the 2016 meetings of the Italian Society of Public Economics (Lecce, September 2016), Hamburg University (November 2016), Bolzano University (November 2016), NTNU (January 2017), Universitat Autònoma de Barcelona (February, 2017) and University of Cyprus (March 2017) for useful comments and suggestions.
} 


\section{INTRODUCTION}

The rise of parties where immigration is a core platform represents a pervasive feature of the recent political landscape. Potential explanations for this development are numerous. For instance, there is a debate over the extent to which they reflect economic, broader social or institutional factors (Arzheimer, 2009; Hatton, 2016). One particular focus is whether the presence of immigrants in a given area influences political views of the electorate. A recent literature suggests that this is the case and demonstrates a positive relationship between the proportion of immigrants in a given area and the receipt of votes by anti-immigration parties (see, for instance, Otto and Steinhardt, 2014; Barone et al., 2016; Sekeris and Vasilakis, 2016). More generally, it has been demonstrated that immigrant inflows lead to an increase in anti-immigrant attitudes in a given location (Halla et al., 2012).

The mechanism explored in this literature is how immigrant inflows shape the attitudes and voting patterns of natives, for instance their tendency to vote for right wing parties with anti-immigration platforms. One of the stated aims of these parties is to either legally restrict entry of immigrants or to deter them in other ways. This leads naturally to an alternative question, does the presence of antiimmigration parties influence the location decisions of immigrants and/or ethnic minority groups? The previous literature treats this as a nuisance factor to be controlled for. For instance, a number of papers use the historical location of migrant networks as a source of exogenous variation in an attempt to hold immigrant sorting constant (Halla et al., 2012; Otto and Steinhardt, 2014; Barone et al., 2016). While recently Dustman et al. (2016) relies on the randomisation of the location of new immigrants to Denmark. We adopt an alternative approach to the existing literature and examine this related, important, but less explored question.

We focus on the case of municipal elections in Northern Italy. This region has seen the ascent of a party with a core anti-immigration political platform, Lega Nord (the 'Northern League'). We construct a dataset of municipal mayoral elections in Italy for the years 2002-2014. Our chief interest is in how anti-immigrant feelings and the ascent of anti-immigrant political parties influences immigrant location decisions. Our approach to disentangling the effect of immigration and local antiimmigrant feeling is to focus on the effect of electing a mayor belonging to or supported by the antiimmigration party Lega Nord on the location decisions of immigrants. We focus on narrow points of comparison between municipalities in a Regression Discontinuity Design (RDD). By comparing municipalities where Lega Nord mayoral candidates won or lost by small margins of victory we argue that we uncover credibly causal effects of anti-immigrants parties on inflows and outflows of immigrants.

To summarise our results, we find that the election of a Lega Nord mayor leads to a reduction in immigrant numbers in the municipality. This appears to be driven by a reduction in inflows into these municipalities, generated by a mixture of immigrants already resident in Italy and newly registered immigrants. These effects are concentrated in the periods immediately following elections and where there is a change in mayoral type. Our evidence suggest the potential for marked changes in 
immigrants' behaviour as a result of recent political events such as the Brexit vote and Trump presidential victory where anti-immigration policies were at the forefront.

\section{BACKGROUND AND DATA}

\section{The Institutional System}

As discussed above we investigate if the election of a Lega Nord Mayor in Italian municipal elections has an impact on the location decisions of immigrants. There are over 8,000 municipalities in Italy, and municipal administrations are responsible of a number of public services, such as the management of public utilities (local roads, water, sewage, garbage collection etc), the provision of public housing and transportation, nursery schools, and assistance to elderly people. Within the administration, Municipal Councils (Consiglio Comunale) are endowed with legislative powers, while executive authority is assigned to a Mayor (Sindaco) who heads an Executive Committee (Giunta Comunale). Given that municipal governments are responsible for a number of very important services that have a great impact on citizens' daily lives, voters are generally highly interested in their composition and performance. This is reflected in high average voter turnout at municipal elections (73\% of eligible voters turned out at the 2009 municipal elections).

Municipal elections in Italy are held every 5 years. ${ }^{1}$ The electoral system for municipalities was changed substantially in 1993 with the introduction of the direct election of the mayor, with different mechanisms according to the size of the city. For municipalities with a population of fewer than 15,000 inhabitants, elections are held with a single ballot and the winning candidate is awarded a majority premium of at least two-thirds of the seats in the Council. For cities with a population above 15,000 , elections are held using a dual ballot (where the second is held only if none of the candidates obtains an absolute majority of votes in the first ballot). For these larger municipalities the winning candidate is awarded a majority premium of at least 60 percent of the seats in the Council. In practice, the average population size of Italian municipalities is 7,018 and only $8 \%$ of municipalities have a population which is greater than 15,000 inhabitants.

In larger municipalities each mayor is endorsed by one or more lists of candidates for the council, each generally representing a party. In smaller municipalities each mayor is endorsed by a single council list. This implies that mayoral candidates of larger municipalities are endorsed by visible multi-party coalitions, while in smaller municipalities coalitions tend to be grouped within adhoc unitary lists. These endorsements happen before the elections, and are clearly signalled during campaign and on the ballot paper. Importantly, no reconfigurations of coalitions are possible after the election.

\footnotetext{
${ }^{1}$ In certain circumstances, the legislature may not survive until the end of its legislative term, e.g. because of a mayor's early resignation or death. This has the added effect that municipal elections are distributed across different calendar years.
} 
Lega Nord (or the Northern League) is a political party that was founded by Umberto Bossi at the end of the Eighties as a federation of several regional parties of Northern Italy. Lega Nord's support base is rooted in regions of Northern Italy (in particular in Lombardia and Veneto, where they receive vote shares of around $20-25 \%$ at the regional level, but also to a lesser extent in Piemonte and Friuli) and it represents the first party in many parts of these regions. At the national level, the percentage of votes in political elections for the Lega Nord was approximately 8-10\% in the Nineties, declined to about 5 percent in 2000s, then rose again to 10-12\% or more in recent years. Since 1994, Lega Nord took part, allied with center-right parties, in several coalition governments led by Silvio Berlusconi. As part of this they obtained several national ministries, most notably the Interior Ministry and the Budget Ministry. Meanwhile, in 1993 a Lega Nord representative was elected as the mayor of Milan. The political platform of the Lega Nord comprises of political and fiscal federalism and regional autonomy (going as far as secession of Northern Italy or "Padania” from Italy), the end of the 'assistance policy' in favour of South Italy, the protection of Northern Italian cultural differences and regional identities, and lower taxation, especially for small firms and entrepreneurs. In this sense, Lega Nord has always taken anti-establishment political positions.

However, in the last two decades Lega Nord has increasingly focused on immigration as a key issue. They have taken an anti-immigration stance and exploited the fear of increasing immigration flows. Using populist rhetoric, Lega Nord has associated immigration with rising criminality, drugs, unemployment, excessive public spending and welfare crisis. In doing so, Lega Nord has, on occasion, used racist and xenophobic propaganda, especially against Roma and immigrants from African countries. ${ }^{2}$ Lega Nord is increasingly aligned with right wing populist parties such as France's National Front and the Freedom Party of Austria. This has occurred in a period in which immigration into Italy has increased substantially. For example, the number of non-Italians resident in Italy increased from 1,340,000 in 2002 to over 5 million in 2015. This increase has been spread across all Italian regions, but particularly in the north of Italy where there are better economic conditions including those areas where Lega Nord experiences strong support.

\section{The Data}

The empirical analysis in this paper is drawn from three data sources.

First, we use administrative data on resident foreigners (both EU and non-EU) in each Italian municipality (at the end of each calendar year), available from ISTAT, the National Statistical Institute from year 2002-2014. ${ }^{3}$ It is a legal requirement for all residents, both Italians and foreigners, to register at the municipality where one resides. The registration is not strictly enforced, but is a

\footnotetext{
${ }^{2}$ For example, the current secretary general of the party recurrently spoke about "bulldozing" to the ground Roma camps and likened the effects of immigration (together with the demographic decline) to "ethnic cleansing”.

${ }^{3}$ Freely available at http://demo.istat.it/index_e.html
} 
requirement for access to a range of public services, such health care provision, school admission, and social and housing benefits. Only legal immigrants can register.

For each year/municipality we observe the following: the number of newly registered foreigners coming from other municipalities; the number of cancelled foreigners going to other municipalities; the number of newly registered foreigners coming from abroad; the number of cancelled foreigners going abroad; the total number of foreigners; the municipal population. Our main dependent variable is the net inflow of foreigners in municipality $i$ in year $t$ as a percentage of its total population (multiplied by 100):

$$
\text { NetInflow }_{i t}=\left(\text { Newly registered Foreigners }_{i t}-\text { Cancelled Foreigners }_{i t}\right) / \text { Total Population }_{i t}
$$

Our second source of data relates to elections. For each election/municipality we have data on the number of votes obtained by each mayoral candidate in the first ballot (and in the second ballot, when it took place). This is obtained from the Italian Interior Ministry. ${ }^{4}$

We focus on roughly 4,000 municipalities in Northern Italian regions (Piemonte, Lombardia, Liguria, Veneto, Friuli-Venezia Giulia, Emilia-Romagna ${ }^{5}$ ) omitting municipalities in geographical areas in which the electoral strength of the Lega Nord is negligible. In addition, we exclude from our sample a number of municipalities in which we do not observe any mayoral candidate supported by Lega Nord. In some cases, especially in small municipalities, the lists competing for elections do not use the national-party labels (such as Lega Nord, Partito Democratico, etc.), but use the generic name "Lista Civica”, translatable as "Local List”. In most cases, this happens in very small municipalities, in which mayoral candidates are indeed non-partisan figures, not belonging to any national political party. At times this may also hide situations in which local politicians with locally-known partisan allegiance decide - for whichever reason - to run under a non-partisan local label.

Finally, to avoid the potential influence of outliers we exclude observations in the $1^{\text {st }}$ and $100^{\text {th }}$ percentile of the net inflow of immigrants. This leaves us with 13,673 municipality/year observations (from 1,803 municipalities). Figure 1 presents the geographical distribution of the municipalities in our estimating sample.

\section{INSERT FIGURE 1}

For each municipality-election combination we observe the elected Mayor, the margin of victory of the winning candidate and the party (or the parties) supporting him/her. We create a dummy, Lega Nord, equal to one when a mayoral candidate who belongs to Lega Nord is elected or a mayor is elected on a coalition ticket that includes Lega Nord and zero when a Lega Nord candidate is

\footnotetext{
${ }^{4}$ See the website: http://elezionistorico.interno.it/index.php?tpel=G

${ }^{5}$ We exclude the region of Trentino-Alto Adige both due to issues with data availability and due to the different electoral system in two of its constituent provinces, Trento and Bolzano.
} 
present but not elected. ${ }^{6}$ We rescale the margin of victory such that it is positive for a victory by a Lega Nord mayoral candidate or a candidate supported by Lega Nord and negative when the winning mayoral candidate was not supported by Lega Nord. In the cases where a second round is held we use these votes as they determine the final electoral outcome.

Finally, we gather data on the geographic and economic characteristics of each municipality (altitude, municipal area, urbanization degree, coastal town, average years of education, average age, employment rate, share of employment in agriculture, industry, services) from ISTAT's Italian Census of Population (from years 2001 and 2011). We also use data on average municipal taxable income that is sourced from the Economic Ministry.

In Table 1 we report descriptive statistics for the main variables used in the analysis. The inflow of immigrants (as a percentage of municipal population) is 1.64 percentage points, the outflow is 1.01 percentage points, and hence the net inflow is 0.63 percentage points. In $28 \%$ of cases of our election outcomes we observe a Lega Nord Mayor. The average margin of victory is $16 \%$. The mean municipal population in our sample is about 15,000 and the average years of education are 9 .

\section{INSERT TABLE 1}

\section{METHODOLOGY}

We start with the following model:

$$
\operatorname{Imm}_{i, t+j}=\gamma \text { LegaNord }_{i t}+\beta \boldsymbol{X}_{i, t+j}+\varepsilon_{i, t+j}
$$

where $\operatorname{Imm}_{i, t+j}$ is a measure of immigration into municipality $i$ at time $t+j$, this is initially NetInflow but in subsequent estimates we consider alternative immigration flow measures. LegaNord is a binary indicator that municipality $i$ has a Mayor elected in year $t$ who is a member of, or is supported by, Lega Nord. We evaluate the impact of the election of a Lega Nord Mayor on the flow of immigrants in the same year of the election $(j=0)$ and in the subsequent years following the election $(j=1,2,3,4) . \boldsymbol{X}$ is a vector of municipality characteristics and collects the intercept. We include in $\boldsymbol{X}$ provincial fixed effects and year fixed effects.. $\varepsilon$ is an error term. The parameter of interest is $\gamma$ and provides the conditional correlation between a Lega Nord Mayor and Municipal migrant flows. As we consider multiple observations for each municipality standard errors are clustered at the municipal level in all regressions.

The main threat to causal interpretation of (1) is the reverse causality that is the focus of the previous literature on immigrants and voting patterns. That is, in our case, existing immigration may

\footnotetext{
${ }^{6}$ Lega Nord runs in about $25 \%$ of municipalities of Northern Italy, comprising two thirds of its population. Just over a third of municipalities in which Lega Nord runs are ruled by a mayor belonging to or supported by Lega Nord. We adopt this approach so as to increase the precision of estimates. In later robustness tests we examine variants where we use alternative approaches.
} 
influence voting patterns for Lega Nord. At the same time, the existence of immigrants may in itself be attractive to prospective migrants, or may be indicative of local amenities that are not captured in $\boldsymbol{X}$. In addition, observed and unobserved local factors (for example, economic conditions) may simultaneously affect both immigrant flows and votes to Lega Nord. All of these provide challenges to causally identifying our relationship of interest.

Our identification approach is to focus on mayoral elections involving a Lega Nord candidate where there was a narrow margin of victory. This forms the basis of a regression discontinuity design (RDD) approach (Lee and Lemieux, 2010; Imbens and Lemieux, 2008) where the main identifying assumption is that all potential confounders (local conditions, amenities, the effect of past immigrant stock/flows) are smooth at the point of a zero margin of victory. Hence, initially we estimate variants of:

$$
\begin{array}{r}
\operatorname{Imm}_{i, t+j}=\beta \boldsymbol{X}_{i, t+j}+\gamma \text { LegaNord }_{i t}+f\left(\text { MarginVictory }_{i t}\right)+ \\
+f\left(\text { MarginVictory }_{i t}\right) * \text { LegaNord }_{i t}+\varepsilon_{i, t+j}
\end{array}
$$

Where $f($ Margin Victory) is a flexible polynomial function of the margin of victory and the interaction term allows for different functional forms on the two sides of the cut-off. In subsequent estimates we also adopt non-parametric, optimal bandwidth based approaches. Assuming that the underlying relationship between the flow of immigrants and the margin of victory is a smooth function, any jump in this relationship when a Lega Nord Mayor is elected represents evidence of a treatment effect of the latter.

A standard concern with this type of identification strategy is that other relevant characteristics may also vary discontinuously with respect to the margin of victory. In fact, a crucial assumption underlying the RDD approach is that unobservable characteristics do not vary discontinuously around the cutoff point and the cutoff rule provides exogenous variations in the treatment "as good as a randomized experiment".

As is standard in the literature, we focus on observed characteristics and test the continuity of the covariate distribution at the threshold to control whether the assumptions of the RDD are satisfied. More precisely, estimating an analogous equation to (2) but where the dependent variable is, in turn, all the predetermined characteristics provides a test of whether a discontinuity is present in any of these variables when a Lega Nord Mayor is elected. In doing so, using the procedure by Calonico, Cattaneo and Titiunik (2014), we use an optimal bandwidth calculated as 15\% above and below the threshold, respectively. We control for the margin of victory and for the interaction term between the LegaNord dummy and the forcing variable, and for provincial and electoral years fixed effects.

Table 2 presents the resultant estimates for a range of municipal characteristics (reported in the first column) at the optimal bandwidth (column 1). Overall, our estimates show that a Lega Nord mayor is not associated with any discontinuity in municipal predetermined characteristics. Since some 
of these characteristics are not balanced we include them as control variables in our estimating equations, although we stress that our main results are not influenced by their inclusion or exclusion.

\section{INSERT TABLE 2}

As an additional examination of our research design in Figure 2 we plot the histogram of the margin of victory around the zero cut-off in 50 bins. Discontinuities in the histogram at the cutoff point would raise concerns that the candidates are able to manipulate the margin of victory. However there does not appear to be any evidence of jumps or grouping of elections around the threshold in Figure 2. This provides a degree of confidence regarding our research design and resultant estimates. Nonetheless in the empirical estimation we examine the robustness of our results to variations in factors such as bandwidth and alternative functional forms.

\section{INSERT FIGURE 2}

\section{RESULTS}

Table 3 provides initial RDD estimates of the effect of the election of a Lega Nord mayor on net migration flows at the municipal level $(j=0, \ldots, 4)$. Initially we estimate on the whole sample. We report a series of increasingly complete models. In column (1) we estimate the impact of a Lega Nord mayor controlling simply for the margin of victory, in column (2) we control for a different linear trend on the two sides of the cut-off. We find that the election of a Lega Nord Mayor in a municipality induces a statistically significant reduction in the net inflow of immigrants of $0.07-0.08$ percentage points ( $p$ value $<0.01)$.

Starting from column (3) we include linear and quadratic terms for the margin of victory. Initially, we include no controls, and we then add year dummies, provincial dummies and, finally, municipal characteristics. The underlying result is that the election of a Lega Nord mayor leads to lower net inflows of immigrants in the municipality. The main estimate of interest is largely unaffected by the choice of control vector and ranges between -0.09 and -0.10 percentage points. This corresponds to about 0.15 of a standard deviation of the dependent variable. Hence, our initial evidence suggests that narrow victories by the Lega Nord Mayors substantially reduce net immigrant flows into the municipality. The coefficients on the forcing variable, the Margin of Victory of Lega Nord, are typically near zero and not statistically significant.

\section{INSERT TABLE 3}

We next seek to examine the sensitivity of this initial finding to Local Linear Regressions and to variations in the bandwidth used in the RDD estimation. The optimal bandwidth - calculated 
following the approach set out by Calonico, Cattaneo and Titiunik (2014) - is 0.152 (below and above the cutoff). The Local Linear estimates with the optimal bandwidth (using only the Margin of Victory in linear form and allowing for a different slope on the two sides of the cut-off) and using a uniform kernel, are provided in the first two columns of Table 4 where we report estimates with and without municipal characteristics. While there is some loss in precision, the point estimates are largely unaffected by this alternative estimation approach with the election of Lega Nord Mayors leading to a -0.082 to -0.085 reduction in the flow of immigrants. For illustrative purposes Figure 3 presents these results where we average our outcome variable into bins of intervals (width of 0.5 percent) of the margin of victory.

One concern might be that the optimal bandwidth, a $-/+15 \%$ margin of victory, is quite wide and includes elections that might be reasonably considered far from close. To investigate this we reestimate our main model after narrowing the bandwidth to half the optimal. These results are reported in Columns 3-4. These generate larger effects of electing a Lega Nord mayor on net migration (-0.11). This suggests that our previous estimates are not an artefact of bandwidth choice, and if anything may represent conservative estimates.

\section{INSERT TABLE 4}

These estimated effects on Net Immigrant Flows might result from a range of underlying migration behaviours. Specifically, they could reflect any combination of inflows and outflows, of immigrants already resident legally in Italy, new legal entrants to Italy, or new registrations of previously illegally resident migrants. Our initial step is to decompose our estimates into inflows and outflows, irrespective of status of the immigrant. Table 4 reports RDD estimates separately for inflows (columns 1-2) and outflows (columns 3-4) that result from analogous models to our earlier net flows models.

These estimates suggest that negative net flow effects reported earlier largely result from a reduction in inflows following the election of a Lega Nord mayor. The estimate of inflows at the initial bandwidth is negative, but not statistically significant at standard levels. Looking at a narrower bandwidth the estimates again become larger and statistically significant. In contrast, the estimate for outflows is never statistically different from zero. While it becomes negative at the narrower bandwidth it is much smaller in absolute magnitude than the effect of inflows. This evidence suggests that our earlier net flows estimate was driven primarily by migrants choosing not to move to municipalities that narrowly elect Lega Nord mayors.

\section{INSERT TABLE 5}


We next seek to understand whether these migration patterns reflect movements of existing legal immigrants within Italy, or alternatively, new registrations of immigrants. It is worth re-iterating two points. First, the movements by existing immigrants are numerically dominant by some margin. Second, we cannot with our data distinguish between new arrivals (in the country) and new registrations (of undocumented immigrants who just acquired legal status), which we group together. Moreover, inflows for this group consist of new registrations in the municipality, while outflows are exits from Italy for individuals currently registered in the municipality. This leads to some care being necessary when interpreting the effects for these groups.

\section{INSERT TABLE 6}

Table 6 presents estimates for flows disaggregated by immigrant type at the optimal bandwidth. The first two columns provide RDD estimates for net flows. For both groups there is a reduction in net flows following the election of a Lega Nord mayor, albeit this is larger and only statistically significant for existing registered foreigners. We then report the same estimates split by inflows and outflows to the municipality. The resultant estimates are imprecise, but do suggest that the flow for the second group are due to new immigrants not entering or registering when Lega Nord mayors are elected, rather than existing foreigners exiting Italy from the municipality. The distinction between entering a municipality and registering is important insofar as one effect of the election of a Lega Nord mayor may be on marginal decisions to enter the formal sector and register as a migrant.

\section{ROBUSTNESS AND EXTENSIONS}

With the relationship between Lega Nord mayoral victories and location decisions of immigration established, we seek to explore a range of issues related to robustness and potential mechanisms.

To this point our measure of Lega Nord mayors has consisted of settings where a Lega Nord member is either the mayoral candidate or where a Lega Nord member is part of the coalition. We seek to examine the robustness of our results to two alternative measures, one more extensive and the other more restrictive.

The first is to more broadly consider centre-right coalitions; this recognises the fact that in some (small) municipalities we cannot separately identify Lega Nord candidates from other centreright candidates, therefore we assume that Lega Nord candidates are present inside centre-right coalitions.

In Table 7 we report estimates in which we include a number of additional municipalities (695) that we previously excluded because we were not able to identify Lega Nord. We now treat centre-right coalitions in these municipalities as coalitions including Lega Nord. As can be seen in 
column (1) and (2), the main results of interest are materially unaffected by this new definition of Lega Nord.

\section{INSERT TABLE 7}

Another concern is that we may be introducing measurement error by treating all Lega Nord coalitions equally, irrespective of the running position of the Lega Nord member in the coalition. To investigate this aspect, we re-estimated our main models identifying coalitions as Lega Nord only if the LN member was the mayoral candidate or deputy mayor. We then exclude all electionmunicipality observations with coalitions where there was only a minor Lega Nord involvement. These estimates are reported in Table 7, columns (3) and (4). These estimates are larger in absolute magnitude and more precise. This indicates that our estimates are driven primarily by Lega Nord candidates and if anything the earlier estimates were conservative. The take home message is that the estimates reported in Table 7 provide us with confidence that is the Lega Nord component of coalitions that are driving our results.

\section{INSERT TABLE 8}

We next explore a range of issues related to the timing of the migration effects of Lega Nord mayoral elections. Our approach has been, in effect, to estimate the impact of Mayoral elections on average annual immigration flows for each 5 years electoral cycle. A natural question is whether there are any temporal patterns in these migration effects. In Table 8 we first build a variable Lag that measures the years spent from the last election ( $\mathrm{Lag}$ is equal to 0 for the year of election, ${ }^{7} 1$ for the following year, and so on). We interact Lag with LegaNord Mayor: in this way, the variable LegaNord Mayor measures the immediate impact of Lega Nord (column 1). We find that Lag*LegaNord Mayor is positive and statistically significant and LegaNord Mayor is negative and larger in magnitude than in previous estimates. This implies that the immediate effect is stronger (about -0.12) and then attenuates as time goes by. After three years the impact is almost halved. In column 2 we estimate the impact considering only the first and second year after the election: we find a strong immediate effect, with the same magnitude as in previous columns. In column 3 we instead estimate considering only third, fourth and fifth year after elections. This confirms the reduction of the impact over time.

\section{INSERT TABLE 9}

In Table 9 we carry out a falsification check in the spirit of Lee (2008). We investigate if the election of a Lega Nord Mayor in year $t$ has any effect on the flows of immigrants in the previous

\footnotetext{
${ }^{7}$ Notice that typically municipal elections are held in May-June.
} 
years. In our RDD framework this should not occur and any anticipation effects would cast doubt on our identification approach, since this would show that immigrant flows are related to some municipal characteristics rather than to a victory or a loss of Lega Nord candidates in close elections.

We estimate two separate models one for the year prior to the election, the other for two years previous. In both cases there is no evidence of a link between a future narrow LN victory and migration patterns. The point estimates in both cases are not statistically significant and the effect sizes are close to zero.

\section{INSERT TABLE 10}

A further issue is that our narrow victories may be either for incumbents (e.g. existing Lega Nord Mayors retaining their position) or municipalities that change mayor. In the latter case we might expect any effect on subsequent immigrant mobility to be larger. Table 10 presents results where we include in addition a dummy indicator for changing mayor, and this indicator interacted with LN mayor victory. The sum of the two estimated coefficients for the interaction provides the additional effect (at the discontinuity) of a LN mayoral victory when this is by a new mayoral team. As reported in Table 10 the effect of a LN mayoral victory is essentially doubled when this is a new mayor.

Finally, we recognize that the negative effect of electing a mayor belonging to the Lega North on the inflows of immigrants in the municipality might derive from a variety of channels. For instance, it may reflect a response to a perceived increase in anti-immigrant feeling. In this sense the election of a mayor with declared anti-immigration views may legitimatize stigmatizing behaviors and generates a more uncomfortable environment for immigrants. This type of effect has been, for instance, widely discussed in the press $^{8}$ in relation to the election of Donald Trump who during his electoral campaign has portrayed immigrants as threats to American values and Americans' safety. Similarly, the recent 'Brexit' referendum in the United Kingdom led to a spike in anti-foreigner crime. At the same time as this channel, the reduction in net migration may also reflect the expectation that a mayor supported by the Lega Nord will undertake political choices, for instance in terms of public expenditure, that will disadvantage immigrants.

\section{INSERT TABLE 11}

Although we cannot investigate the first channel directly, we seek to provide suggestive evidence on the second. We are able to observe the choices made by mayors in terms of public expenditure. More precisely, we use data from the local councils' balance sheets to consider expenditures in the areas of social services. We estimate an analogue of equation (2) but considering as the dependent variable the fraction of social expenditures (the sum of expenditures devoted to social housing, to social assistance and care on total expenditures). While not solely directed towards nonItalians, the social expenditures are used extensively by immigrants due to their demographic make-

\footnotetext{
${ }^{8}$ See for instance http://www.vox.com/2016/11/17/13639138/trump-hate-crimes-attacks-racism-xenophobiaislamophobia-schools
} 
up. As shown in column (1) of Table 11, we find a negative and weakly statistically significant effect of Lega Nord mayoral victories on these expenditures. This pattern may simply reflect the fact that Lega Nord mayors are more likely to be fiscally conservative. To explore this in column (2) we perform the same exercise on another major part of municipal expenditure, that directed towards elderly people, a group in which immigrants are typically a very small minority. There is neither a statistically significant nor economically meaningful effect of Lega Nord Mayors. Finally, in column (3) we consider as outcome variable total expenditure (in thousands of euros) and again we do not find any statistically significant effect of Lega Nord Mayors. This fits with recent regression discontinuity based evidence that suggests no difference in overall municipal expenditure according to Mayoral political alignment in Italy (Bracco et al 2015). While far from definitive, this exercise suggests that part of the response of immigrants to Lega Nord mayoral victories may reflect reactions to the reduction in the provision of public services. This is an avenue that future research should consider.

\section{CONCLUSION}

There appears to be a rapid and marked increase in the popularity and vote share of anti-immigration parties across a range of jurisdictions. While previous research considers the potential causes of this, and the extent to which immigration itself may generate support for these parties, little is known about how these patterns influence migration decisions. We provide evidence on this by examining mayoral elections in Northern Italy, and the effect of victories by Italy’s primary anti-immigration party, Lega Nord.

We use a Regression Discontinuity framework to disentangle the causal effect of electing a Lega Nord mayor from municipal factors related to the electoral support for Lega Nord and from other potential omitted variables, by focusing on municipalities in which Lega Nord candidates win or lose the electoral competition by narrow margins.

We demonstrate that immigrant's location decisions do react to the election of mayors of, or supported by, Lega Nord. Specifically, these events have marked effects on net flows of immigration in municipalities. This appears to be driven almost entirely by individuals choosing not to move into these places following the election of Lega Nord mayors. These decisions are concentrated in the early periods following the election and reflect a mixture of the choices of existing foreigners resident and registered in Italy and newly registered immigrants. That these narrow victories of parties that utilise anti-immigrant rhetoric have a marked effect on immigrant behaviour is also noteworthy given the recent Brexit referendum and Donald Trump presidential victory.

A question naturally is what drives these patterns? We provide suggestive evidence that, as well as the effect of increases in local hostility towards foreigners, it could also reflect changes in public provision of services demanded more by foreigners. 
The combination of greater immigrant flows into Europe and the rise of far-right parties makes understanding the mechanisms that drive these location effects highly relevant and an important focus for future research. 


\section{REFERENCES}

Arzheimer, K. (2009). Contextual Factors and the Extreme Right Vote in Western Europe, 19802002. American Journal of Political Science. 53, 259-275.

Barone, G., D'Ignazio, A., de Blasio, G., \& Naticchioni, P. (2016). Mr. Rossi, Mr. Hu and politics. The role of immigration in shaping natives' voting behavior. Journal of Public Economics, 136, 1-13.

Bracco, E., Lockwood, B., Porcelli and Redoano, M. (2017) Intergovernmental grants as signals and the alignment effect: Theory and evidence. Journal of Public Economics, 123, 78-91.

Calonico, S., Cattaneo, M. D., \& Titiunik, R. (2014). Robust Nonparametric Confidence Intervals for Regression - Discontinuity Designs. Econometrica, 82(6), 2295-2326.

Dustmann, C., Vasiljeva, K., \& Damm, A. P. (2016). Refugee Migration and Electoral Outcomes. CReAM DP, 19, 16.

Halla, M., Wagner, A. F., \& Zweimüller, J. (2012). Does Immigration into Their Neighborhoods Incline Voters Toward the Extreme Right? The Case of the Freedom Party of Austria. IZA Discussion Paper No. 6575.

Hatton, T. J. (2016). Immigration, public opinion and the recession in Europe. Economic Policy, 31(86), 205-246.

Imbens, G. W., and Lemieux, T. (2008). Regression discontinuity designs: A guide to practice. Journal of Econometrics, 142(2), 615-635.

Lee, D. S. (2008), “Randomized experiments from non-random selection in U.S. House elections”, Journal of Econometrics, 142: 675-697.

Lee, D. S., and Lemieux, T. (2010). Regression discontinuity designs in economics. Journal of Economic Literature, 48(2), 281-355.

Mayda, A. M. (2006). Who is against immigration? A cross-country investigation of individual attitudes toward immigrants. The Review of Economics and Statistics, 88(3), 510-530.

Mayda, A. M., Peri, G., \& Steingress, W. (2016). Immigration to the US: A problem for the Republicans or the Democrats? (No. w21941). National Bureau of Economic Research.

McCrary, J. (2008). Manipulation of the running variable in the regression discontinuity design: A density test. Journal of Econometrics, 142(2), 698-714.

Otto, A. H., \& Steinhardt, M. F. (2014). Immigration and election outcomes—Evidence from city districts in Hamburg. Regional Science and Urban Economics, 45, 67-79.

Sekeris, P., \& Vasilakis, C. (2016). The Mediterranean Refugees Crisis and Extreme Right Parties: Evidence from Greece. MPRA Working Paper No. 72222.

Steinmayr, A. (2016). Exposure to Refugees and Voting for the Far-Right:(Unexpected) Results from Austria. IZA Discussion Paper No. 9790. 
Figure 1 Regions with a Lega Nord Presence (Left), Municipalities where Lega Nord ran for Municipal Elections (Centre) and Municipalities where Lega Nord was part of the Ruling Coalition (Right). All 2002-2014.
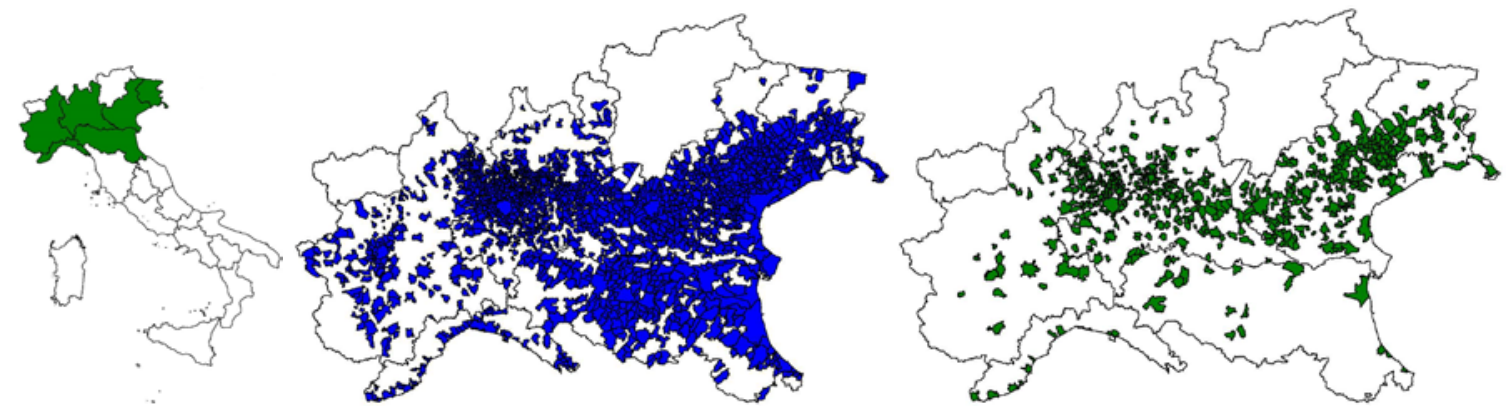
Figure 2 The Density of Margin of Victory Centred Around the Zero Margin

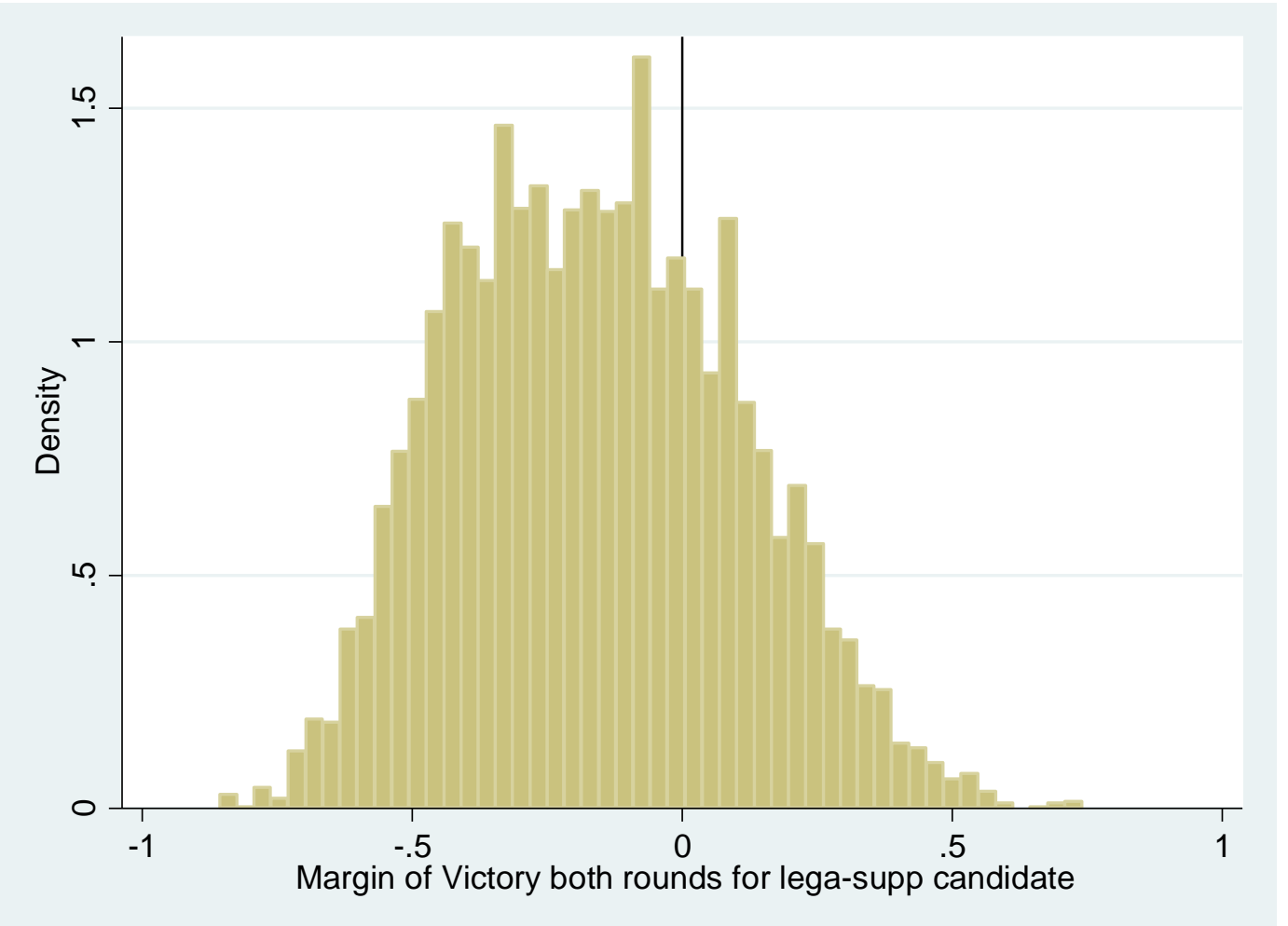


Figure 3. The Effect of Electing a Lega Nord Mayor on Net Immigrant Flows

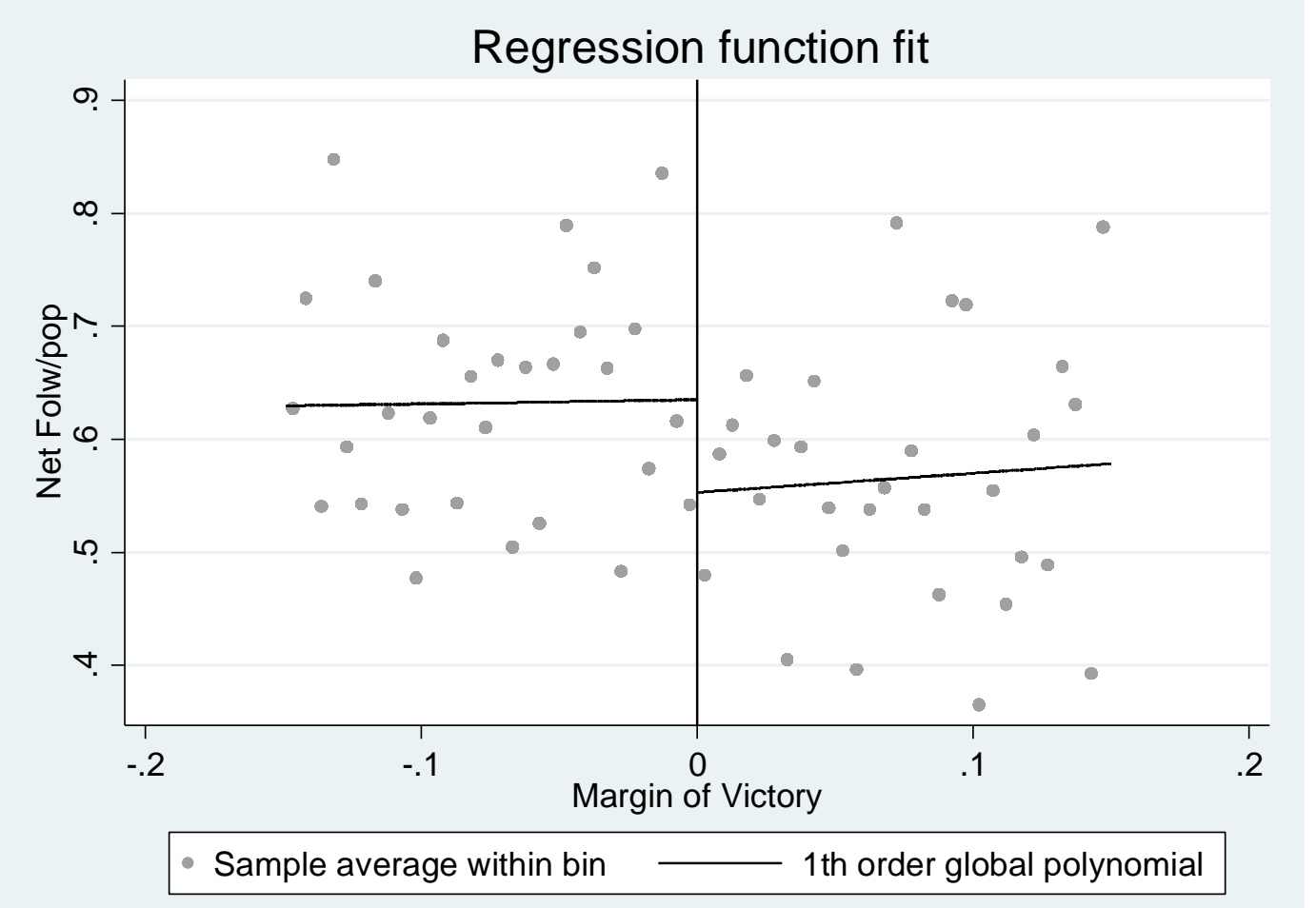

Notes. The black line is a first-order polynomial in Margin of Victory fitted separately on each side of the margin of victory thresholds at zero. Scatter points are averaged over 0.5 percent intervals. 
Table 1. Municipal Descriptive Statistics, 2002-2014

\begin{tabular}{lccccc}
\hline \hline Variable & Mean & Std. Dev. & Min & Max & Obs \\
\hline Net Inflow & 0.633 & 0.622 & -1.018 & 2.798 & 13,673 \\
Inflow (total) & 1.649 & 0.872 & 0.000 & 6.486 & 13,673 \\
Outflow (total) & 1.016 & 0.651 & 0.000 & 5.443 & 13,673 \\
LegaNord Mayor & 0.280 & 0.449 & 0.000 & 1.000 & 13,673 \\
Margin of Victory & -0.159 & 0.262 & -0.857 & 0.740 & 13,673 \\
Population & 15.033 & 49.137 & 0.043 & 1164.240 & 13,673 \\
Education & 9.068 & 0.640 & 6.558 & 12.042 & 13,671 \\
Income & 20.060 & 3.363 & 8.776 & 44.663 & 13,673 \\
Area sq.km & 0.031 & 0.043 & 0.001 & 0.653 & 13,672 \\
Altitude & 0.183 & 0.185 & 0.000 & 2.035 & 13,672 \\
Urban & 0.360 & 0.480 & 0.000 & 1.000 & 13,666 \\
Share Agric. & 0.041 & 0.037 & 0.002 & 0.370 & 13,657 \\
Share Industry & 0.380 & 0.093 & 0.100 & 0.750 & 13,657 \\
Share Trade & 0.182 & 0.037 & 0.075 & 0.685 & 13,657 \\
\hline \hline
\end{tabular}

Source: Istat Resident Foreigners; Historical Archive of Municipal Election, Interior Ministry; ISTAT Italian Census of Population 
Table 2. Regression Discontinuity Estimates of the Effect of Lega Nord Victory on Predetermined Municipal Characteristics.

\begin{tabular}{lc}
\hline Dependent Variables & $(1)$ \\
& Optimal Bandwidth \\
\hline Population & 0.875 \\
& $(5.796)$ \\
Education & -0.041 \\
& $(0.058)$ \\
Income & -0.265 \\
& $(0.266)$ \\
Area sq.km & -0.002 \\
Altitude & $(0.003)$ \\
& 0.004 \\
Urban & $0.014)$ \\
& -0.044 \\
Share Agriculture & $(0.045)$ \\
& 0.000 \\
Share Industry & $(0.003)$ \\
Share Trade & 0.009 \\
& $(0.009)$ \\
\hline Observations & -0.004 \\
\hline Coeffcist & $(0.004)$ \\
\hline
\end{tabular}

Coefficients on LegaNord Mayor from RD regression in which the dependent variable is, in turn, the variable on the first column. The control variables are Margin of Victory, Margin of Victory* LegaNord Mayor, year dummies and provincial dummies. 
Table 3. The Effect of Electing a Lega Nord Mayor on Net Immigrant Flows, Parametric RDD Estimates.

\begin{tabular}{|c|c|c|c|c|c|c|}
\hline & (1) & (2) & (3) & (4) & (5) & (6) \\
\hline Lega Nord (LN) Mayor & $\begin{array}{c}-0.072^{* * *} \\
(0.027)\end{array}$ & $\begin{array}{c}-0.081^{* * *} \\
(0.028)\end{array}$ & $\begin{array}{c}-0.093^{* *} \\
(0.040)\end{array}$ & $\begin{array}{c}-0.108^{* * *} \\
(0.036)\end{array}$ & $\begin{array}{c}-0.103 * * * \\
(0.034)\end{array}$ & $\begin{array}{c}-0.087 * * * \\
(0.033)\end{array}$ \\
\hline Margin of Victory (MV) & $\begin{array}{c}-0.002 \\
(0.048)\end{array}$ & $\begin{array}{c}-0.021 \\
(0.053)\end{array}$ & $\begin{array}{l}-0.241 \\
(0.182)\end{array}$ & $\begin{array}{c}0.193 \\
(0.163)\end{array}$ & $\begin{array}{c}0.328 * * \\
(0.155)\end{array}$ & $\begin{array}{c}0.337 * * \\
(0.148)\end{array}$ \\
\hline MV * LN Mayor & & $\begin{array}{c}0.105 \\
(0.126)\end{array}$ & $\begin{array}{c}0.806 * * \\
(0.353)\end{array}$ & $\begin{array}{c}0.109 \\
(0.326)\end{array}$ & $\begin{array}{l}-0.139 \\
(0.315)\end{array}$ & $\begin{array}{c}-0.304 \\
(0.310)\end{array}$ \\
\hline $\mathrm{MV}^{2}$ & & & $\begin{array}{c}-0.350 \\
(0.277)\end{array}$ & $\begin{array}{c}-0.118 \\
(0.247)\end{array}$ & $\begin{array}{c}0.084 \\
(0.235)\end{array}$ & $\begin{array}{c}0.364 \\
(0.227)\end{array}$ \\
\hline $\mathrm{MV}^{2} *$ LN Mayor & & & $\begin{array}{l}-0.658 \\
(0.644)\end{array}$ & $\begin{array}{l}-0.521 \\
(0.611)\end{array}$ & $\begin{array}{l}-0.441 \\
(0.591)\end{array}$ & $\begin{array}{c}-0.384 \\
(0.607)\end{array}$ \\
\hline Population & & & & & & $\begin{array}{c}0.001^{* * *} \\
(0.000)\end{array}$ \\
\hline Education & & & & & & $\begin{array}{c}0.116 * * * \\
(0.035)\end{array}$ \\
\hline Income & & & & & & $\begin{array}{c}-0.026 * * * \\
(0.007)\end{array}$ \\
\hline Area $\left(\mathrm{km}^{2}\right)$ & & & & & & $\begin{array}{c}0.762 * * * \\
(0.252)\end{array}$ \\
\hline Altitude & & & & & & $\begin{array}{c}-0.681 * * * \\
(0.078)\end{array}$ \\
\hline Urban & & & & & & $\begin{array}{c}0.034 \\
(0.023)\end{array}$ \\
\hline Year dummies & $\mathrm{NO}$ & $\mathrm{NO}$ & $\mathrm{NO}$ & YES & YES & YES \\
\hline Provincial dummies & NO & NO & NO & NO & YES & YES \\
\hline Municipal characteristics & NO & NO & NO & NO & NO & YES \\
\hline Observations & 13673 & 13673 & 13673 & 13673 & 13670 & 13648 \\
\hline R-squared & 0.003 & 0.003 & 0.004 & 0.196 & 0.244 & 0.283 \\
\hline
\end{tabular}

The table reports OLS estimates. The dependent variable is Net Immigrant Flow. Standard errors (reported in parentheses) are corrected for heteroskedasticity and clustered at the municipal level. ${ }^{*} p<0.10,{ }^{* *} p<0.05$, $* * * p<0.01$ 
Table 4. The Effect of Electing a Lega Nord Mayor on Net Immigrant Flows. Local Linear Regressions and Alternative Bandwidths.

\begin{tabular}{lcccc}
\hline & $(1)$ & $(2)$ & $(3)$ & $(4)$ \\
& \multicolumn{1}{c}{ Optimal Bandwidth } & $0.5^{*}$ Optimal Bandwidth \\
\hline Lega Nord (LN) Mayor & $-0.085^{*}$ & $-0.082^{* *}$ & $-0.127^{*}$ & $-0.111^{*}$ \\
& $(0.045)$ & $(0.041)$ & $(0.065)$ & $(0.061)$ \\
Margin of Victory (MV) & 0.252 & 0.361 & 0.477 & -0.112 \\
& $(0.358)$ & $(0.334)$ & $(0.975)$ & $(0.898)$ \\
MV* LN Mayor & -0.050 & -0.115 & 0.445 & 1.149 \\
& $(0.534)$ & $(0.490)$ & $(1.361)$ & YES \\
\hline Year dummies & YES & YES & YES & YES \\
Provincial dummies & YES & YES & YES & YES \\
Municipal characteristics & NO & YES & 2415 & 2415 \\
\hline Observations & 4832 & 4829 & 0.241 & 0.308 \\
R-squared & 0.253 & 0.299 & \\
\hline
\end{tabular}

The table reports OLS estimates. The dependent variable is Net Immigrant Flow. Standard errors (reported in parentheses) are corrected for heteroskedasticity and clustered at the municipal level. $* p<0.10, * * p<0.05$, $* * * p<0.01$. 
Table 5. The Effect of Electing a Lega Nord Mayor on Immigrant Inflows and Outflows, Local Linear Regressions.

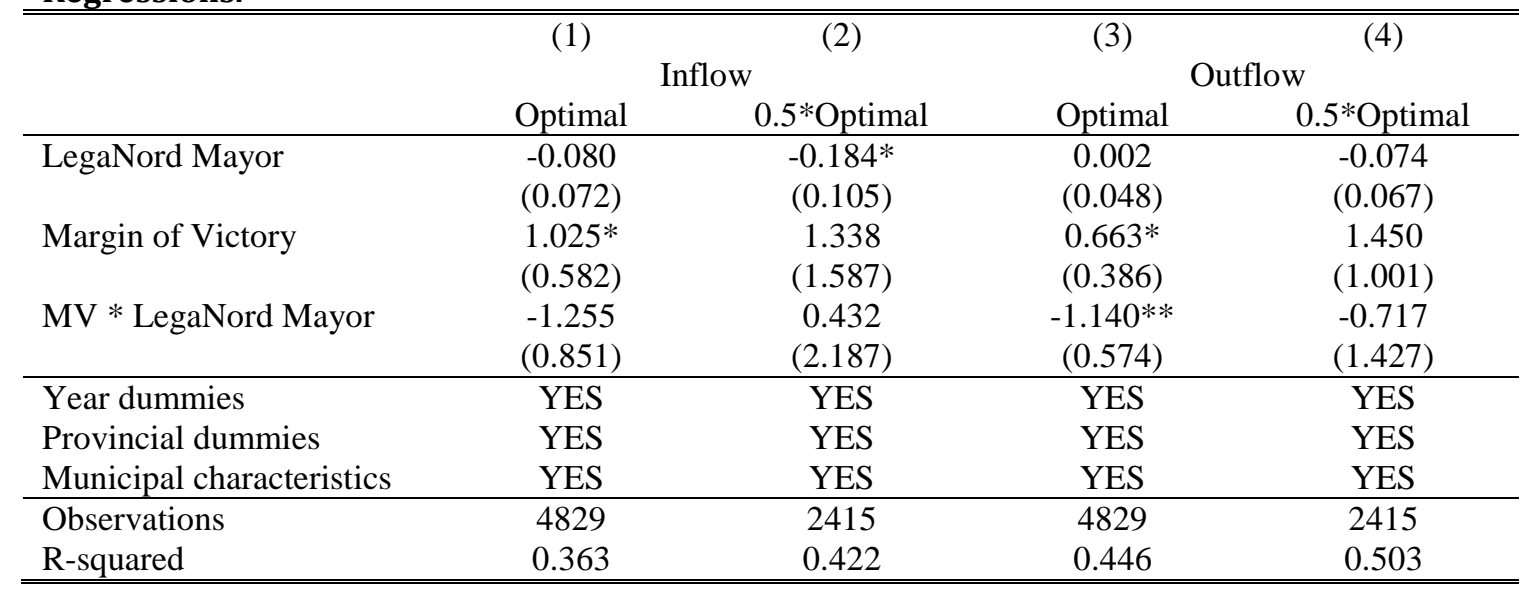

The table reports OLS estimates. Standard errors (reported in parentheses) are corrected

for heteroskedasticity and clustered at the municipal level. ${ }^{*} p<0.10,{ }^{* *} p<0.05, * * * p<0.01$. 
Table 6. Lega Nord and Immigrant flows from other municipalities / new registrations, Local Linear Regressions.

\begin{tabular}{|c|c|c|c|c|c|c|}
\hline & $(1)$ & $(2)$ & (3) & (4) & (3) & (4) \\
\hline & \multicolumn{2}{|c|}{ Net Flows } & \multicolumn{2}{|c|}{ Inflows } & \multicolumn{2}{|c|}{ Outflows } \\
\hline & $\begin{array}{l}\text { (Other } \\
\text { mun.) }\end{array}$ & $\begin{array}{l}\text { (Abroad/New } \\
\text { registrants) }\end{array}$ & $\begin{array}{l}\text { (Other } \\
\text { mun.) }\end{array}$ & $\begin{array}{c}\text { (New } \\
\text { Registrants) }\end{array}$ & $\begin{array}{l}\text { (Other } \\
\text { mun.) }\end{array}$ & to Abroad \\
\hline \multirow[t]{2}{*}{ Lega Nord (LN) Mayor } & $-0.057 * * *$ & -0.043 & -0.029 & -0.045 & 0.028 & -0.002 \\
\hline & $(0.021)$ & $(0.029)$ & $(0.031)$ & $(0.031)$ & $(0.029)$ & $(0.009)$ \\
\hline \multirow[t]{2}{*}{ Margin of Victory (MV) } & 0.191 & $0.409 *$ & 0.295 & $0.443^{*}$ & 0.103 & 0.034 \\
\hline & $(0.175)$ & $(0.238)$ & $(0.251)$ & $(0.262)$ & $(0.248)$ & $(0.077)$ \\
\hline \multirow[t]{2}{*}{ MV * LN Mayor } & 0.148 & -0.426 & -0.468 & -0.432 & $-0.616^{*}$ & -0.006 \\
\hline & $(0.255)$ & $(0.344)$ & $(0.359)$ & $(0.376)$ & $(0.358)$ & $(0.112)$ \\
\hline Year dummies & YES & YES & YES & YES & YES & YES \\
\hline Provincial dummies & YES & YES & YES & YES & YES & YES \\
\hline $\begin{array}{l}\text { Municipal } \\
\text { characteristics }\end{array}$ & YES & YES & YES & YES & YES & YES \\
\hline Observations & 4826 & 4826 & 4826 & 4826 & 4826 & 4826 \\
\hline R-squared & 0.071 & 0.434 & 0.336 & 0.409 & 0.368 & 0.174 \\
\hline
\end{tabular}

The table reports OLS estimates. Standard errors (reported in parentheses) are corrected for heteroskedasticity and clustered at the municipal level. ${ }^{*} p<0.10$, ** $p<0.05$, *** $p<0.01$. 
Table 7. Robustness of Main Estimates of Net Inflows to Alternative Lega Nord Measures, Local Linear Regressions.

\begin{tabular}{lcccc}
\hline & $\begin{array}{c}(1) \\
\text { Optimal } \\
\text { Bandwidth }\end{array}$ & $\begin{array}{c}(2) \\
\text { Optimal } \\
\text { Bandwidth *.5 }\end{array}$ & $\begin{array}{c}(1) \\
\text { Optimal } \\
\text { Bandwidth }\end{array}$ & $\begin{array}{c}(2) \\
\text { Optimal } \\
\text { Bandwidth *.5 }\end{array}$ \\
\hline Lega Nord/Centre Right Coalition & $\begin{array}{c}-0.060^{*} \\
(0.034)\end{array}$ & $-0.135^{* * *}$ & & \\
Lega Nord Mayor/Deputy Only & & & $-0.129 * *$ & $-0.215^{* *}$ \\
& & & $(0.066)$ & $(0.103)$ \\
Margin of Victory & 0.166 & -0.198 & 0.458 & 0.052 \\
& $(0.247)$ & $(0.909)$ & $(0.351)$ & $(0.981)$ \\
\hline Year dummies & YES & YES & YES & YES \\
Provincial dummies & YES & YES & YES & YES \\
Municipal characteristics & YES & YES & YES & YES \\
\hline Observations & 6669 & 3495 & 3411 & 1664 \\
$R^{2}$ & 0.294 & 0.306 & 0.304 & 0.308 \\
\hline
\end{tabular}

The table reports OLS estimates. Standard errors (reported in parentheses) are corrected for heteroskedasticity and clustered at the municipal level.* $p<0.10,{ }^{* *} p<0.05$, ${ }^{* * *} p<0.01$. 
Table 8. The Timing of Lega Nord Effects on Net Inflows, Local Linear Regressions.

\begin{tabular}{lccc}
\hline & $(1)$ & $\begin{array}{c}(2) \\
\text { Only first and second } \\
\text { year }\end{array}$ & $\begin{array}{c}(3) \\
3^{\text {rd }}-5^{\text {th }} \text { years }\end{array}$ \\
\hline LegaNord Mayor & $-0.117^{* * *}$ & $-0.113^{* *}$ & -0.068 \\
& $(0.045)$ & $(0.053)$ & $(0.048)$ \\
Lag* LegaNord Mayor & $0.018^{*}$ & & 0.433 \\
& $(0.010)$ & 0.359 & $(0.393)$ \\
Margin of Victory (MV) & 0.359 & $(0.420)$ & -0.356 \\
& $(0.334)$ & 0.147 & $(0.565)$ \\
MV* LegaNord Mayor & -0.103 & $(0.617)$ & YES \\
& $(0.491)$ & YES & YES \\
\hline Year dummies & YES & YES & 2799 \\
Provincial dummies & YES & YES & 0.302 \\
\hline Obunicipal characteristics & YES & 2030 & 0.318 \\
$R^{2}$ & 4829 & 0.299 & \\
\hline
\end{tabular}

The table reports OLS estimates. Standard errors (reported in parentheses) are corrected for heteroskedasticity and clustered at the municipal level. ${ }^{*} p<0.10,{ }^{* *} p<0.05$, *** $p<0.01$. 
Table 9. The Impact of Lega Nord Mayor Elections on Net Immigrant Flow in year t-1 and t-2, Local Linear Regressions.

\begin{tabular}{lcc}
\hline & $(1)$ & $(2)$ \\
& $\mathrm{t}-1$ & $\mathrm{t}-2$ \\
\hline LegaNord Mayor & -0.020 & 0.006 \\
& $(0.069)$ & $(0.061)$ \\
Lag* LegaNord Mayor & 0.075 & -0.110 \\
& $(0.321)$ & $(0.276)$ \\
Margin of Victory (MV) & -0.001 & -0.208 \\
& $(0.743)$ & $(0.540)$ \\
MV* LegaNord Mayor & 2717 & 2677 \\
& 0.266 & 0.262 \\
\hline Year dummies & YES & YES \\
Provincial dummies & YES & YES \\
Municipal characteristics & YES & YES \\
\hline Observations & 2717 & 2717 \\
$R^{2}$ & 0.266 & 0.266 \\
\hline
\end{tabular}

The table reports OLS estimates. Standard errors (reported in parentheses) are corrected for heteroskedasticity and clustered at the municipal level. $* p<0.10$, ** $p<0.05$, *** $p<0.01$. 
Table 10. Lega Nord Effects, NewMayors and Incumbents. Impact on Net Inflow, Local Linear Regressions.

\begin{tabular}{lccc}
\hline & $(1)$ & $(2)$ & $(3)$ \\
\hline LegaNord Mayor (LN) & $-0.106^{* *}$ & $-0.089^{*}$ & $-0.094^{* *}$ \\
& $(0.052)$ & $(0.051)$ & $(0.047)$ \\
Switcher*LN & $-0.103^{* *}$ & $-0.149 * * *$ & $-0.107^{* *}$ \\
& $(0.052)$ & $(0.051)$ & $(0.045)$ \\
Switcher & $0.134^{* * *}$ & $0.172^{* * *}$ & $0.142^{* * *}$ \\
& $(0.033)$ & $(0.033)$ & $(0.029)$ \\
Margin of Victory & 0.103 & 0.282 & $0.299^{*}$ \\
MV) & $(0.189)$ & $(0.182)$ & $(0.175)$ \\
MV $* \quad$ LegaNord & 0.293 & -0.066 & -0.191 \\
Mayor & $(0.363)$ & $(0.357)$ & $(0.355)$ \\
& & & YES \\
Year dummies & YES & YES & YES \\
$\begin{array}{l}\text { Provincial dummies } \\
\text { Municipal } \\
\text { characteristics }\end{array}$ & NO & NOS & YES \\
\hline Observations & NO & & 11237 \\
R-squared & 11257 & 11255 & 0.272 \\
\hline
\end{tabular}

The table reports OLS estimates. Standard errors (reported in parentheses) are corrected for heteroskedasticity and clustered at the municipal level. * $p<0.10, * * p<0.05$, *** $p<0.01$. 
Table 11 The Effect of Electing a Lega Nord Mayor on Municipal Expenditure Expenditure. Local Linear Regressions.

\begin{tabular}{lccc}
\hline & Social Expenditure & Elderly Expenditure & Total Expenditure \\
\hline Lega Nord (LN) Mayor & $-0.874^{*}$ & 0.021 & 13.452 \\
& $(0.489)$ & $(0.265)$ & $(14.835)$ \\
Margin of victory (MV) & $7.183^{* *}$ & -0.840 & -162.912 \\
& $(3.618)$ & $(1.697)$ & $(138.350)$ \\
MV*LN Mayor & 0.629 & 2.577 & 115.785 \\
& $(5.963)$ & $(3.203)$ & $(228.112)$ \\
\hline Year dummies & YES & YES & YES \\
Provincial dummies & YES & YES & YES \\
Municipal characteristics & YES & 4197 & 4225 \\
\hline Observations & 4114 & 0.1229 & 0.9476 \\
R-squared & 0.2922 & \\
\hline
\end{tabular}

The table reports OLS estimates. Standard errors (reported in parentheses) are corrected for heteroskedasticity and clustered at the municipal level.. ${ }^{*} p<0.10,{ }^{* *} p<0.05,{ }^{* * *} p<0.01$. 